\title{
STUDY LITERATURE TENTANG PEMBERIAN MINUMAN KUNYIT ASAM TERHADAP TINGKAT NYERI MENSTRUASI PADA REMAJA PUTRI
}

\author{
Tiara Widiatami ${ }^{1)}$ Melyana Nurul $\mathrm{W}^{2)}$ Admini $^{3)}$ \\ E-mail address: timiiaraa @gmail.com
}

\begin{abstract}
Menstrual pain or dysmenorrhea is a gynecological complaint caused by an imbalance of the progesterone hormone in the blood that causes pain and most often occurs in women. Women who experience menstrual pain usually produce prostaglandin 10 times more than women who do not experience menstrual pain. This prostaglandin causes an increase in uterine contractions that causes menstrual pain.

Research purposes: to identify literature related to acidic turmeric drinks to menstrual pain levels.

The type of literature study conducted is using analytical metadata using literature (literature review) that can explain the benefits of acid turmeric drinks to reduce pain levels during menstruation.

Menstrual pain is abdominal pain that comes from uterine cramps that occurs during menstruation. Usually occurs at the onset of menstruation and lasts several hours to several days until it reaches the peak of pain. Menstrual pain is the most common problem in adolescent and adult women, but is a different condition for many women who influence health-related quality of life. Menstrual pain, the fact that women cannot act normally can have an economic impact, because it relates to expenditures spent on purchasing, and medical care. To reduce prices on dysmenorrhea respondents, what we did was to give acidic turmeric drinks to respondents who were conceived during menstruation. Acidic turmeric drinks are drinks that are processed with the main ingredients of turmeric and acid. Naturally turmeric is believed to have active ingredients that can be used as analgesic, antipyretic and anti-inflammatory, so it is also acidic (tamarind) which has active ingredients as anti-inflammatory, antipyretic and sedative.
\end{abstract}

Keywords: menstrual pain; sour turmeric drinks

${ }^{1)}$ Borneo Health Sciences College Cendekia Medika Pangkalan Bun

2) Poltekkes Kemenkes Semarang

${ }^{3)}$ Puskesmas I Wangon, Banyumas

\section{Pendahuluan}

Nyeri menstruasi atau dysmenorrhea ialah keluhan ginekologi yang diakibatkan karena ketidak-seimbangan hormon progesteron yang berada dalam darah sehingga mengakibatkan timbulnya rasa nyeri dan yang paling sering terjadi pada perempuan. Perempuan yang mengalami nyeri menstruasi biasanya memproduksi prostaglandin 10 kali lebih banyak dibandingkan dengan perempuan yang tidak mengalami nyeri menstruasi. Prostaglandin ini menyebabkan meningkatnya kontraksi uterus yang 
menimbulkan rasa nyeri pada saat menstruasi.

Angka kejadian nyeri menstruasi di seluruh dunia masih sangat banyak, persentase kejadian nyeri menstruasi di dunia rata-rata lebih dari $50 \%$ atau berkisar sebesar $15,8-89,5 \%$ wanita di setiap negara mengalami nyeri menstruasi. Prevalensi nyeri menstruasi di Amerika Serikat diperkirakan sebesar 45-90\%, kemudian di India adalah sebesar $75 \%$ dan di Mesir angka prevalensinya telah diperkirakan sebesar 75\% (American Family Physician, 2014). Khusus di Indonesia angka nyeri menstruasi tipe primer adalah $54,8 \%$ dan tipe sekunder adalah $9,36 \%$.

Beberapa perempuan yang mengalami nyeri menstruasi mengatasi serta menyembuhkannya dengan mengkonsumsi obat-obatan anti nyeri secara berkala. Namun sifat obat tersebut hanya menghilangkan rasa sakit dan akan menimbulkan ketergantungan terhadap obat tersebut. Jika dikonsumsi dalam jangka panjang dapat memberikan efek negatif bagi kesehatan. Penggunaan obat-obatan akan memberikan efek samping seperti gangguan pada lambung, anemia dan yang lebih parah adalah dampak mental psikologis yang membuat penderitanya tersugesti dan tidak bisa melepaskan diri dari obat. Mereka menganggap agar tidak nyeri pada saat menstruasi harus minum obat (Anugroho \& Wulandari, 2011).

Selain dengan obat-obatan, rasa nyeri juga bisa dikurangi dengan istirahat yang cukup, olahraga yang teratur, pemijatan dan kompres hangat. Selain itu nyeri menstruasi juga bisa diobati dengan menggunakan tumbuhan herbal antara lain tapak liman, temu putih, kunyit dan sidaguri.
Data menurut lndustri Obat Tradisional (IOT) dan Industri Kecil Obat Tradisional (IKOT) dari 4.187 terdapat 40\% masyarakat memanfaatkan kunyit sebagai pengobatan dan $10 \%$ masyarakat mengkonsumsi kunyit untuk mengurangi nyeri waktu menstruasi (Leli, Rahmawati \& Atik, 2011).

Produk herbal atau jamu maupun fitofarmaka sudah menjadi pilihan alternatif bagi perempuan untuk mengurangi nyeri menstruasi tanpa mendapat efek samping (Kylenorton, 2010). Salah satu diantaranya adalah dengan minum kunyit asam. Secara alamiah kunyit mengandung senyawa fenolik yang dipercaya dapat digunakan sebagai antioksidan, analgetika, anti-mikroba, anti-inflamasi dan dapat membersihkan darah. Senyawa aktif yang terkandung pada kunyit, yaitu curcumine (Sina, 2012). Asam jawa memiliki kandungan aktif, yaitu anthocyanin yang dapat digunakan sebagai antipiretika dan anti-inflamasi. Secara lebih spesifik kandungan curcumine dan anthocyanin dapat menghambat terjadinya reaksi cyclooxygenase (COX) sehingga dapat menghambat dan mengurangi terjadinya inflamasi, kemudian akan mengurangi serta menghambat kontraksi uterus yang menyebabkan nyeri menstruasi.

Hasil dari penelitian sebelumnya menunjukkan bahwa kandungan curcumine pada kunyit aman dan tidak menyebabkan toksik jika dikonsumsi manusia, jumlah aman curcumine yang boleh dikonsumsi oleh manusia adalah $100 \mathrm{mg} /$ hari (Marlina, 2012).

Penelitian Hamed Fanaei dkk pada tahun 2016, dalam penelitiannya yang berjudul "Effect of curcumin on 
serum brain-derived neurotrophic factor levels in women with premenstrual syndrome: A randomized, double-blind, placebocontrolled trial" mengatakan bahwa pengaruh curcumine dapat menurunkan gejala suasana hati, perilaku dan nyeri menstruasi (PMS) (Hamed Fanaei dkk, 2016).

Didukung juga dengan penelitian Marsaid dkk (2017) dalam penelitiannya yang berjudul "Efektifitas pemberian ekstrak kunyit asam terhadap penurunan dismenore pada remaja putri di desa tambang kecamatan pudak Kabupaten ponorogo" dengan hasil bahwa ekstrak kunyit asam efektif menurunkan dismenore pada remaja putri di desa tambang kecamatan pudak kabupaten ponorogo (Marsaid dkk, 2017).

\section{Metode Penelitian}

Jenis study literature yang dilakukan adalah menggunakan metadata analisis dengan tinjauan literatur (literature review) yang mencoba menggali tentang manfaat minuman kunyit asam untuk mengurangi tingkat nyeri saat menstruasi. Sumber untuk melakukan tinjauan ini meliputi pencarian secara elektronik dengan menggunakan beberapa database, antara lain pada Science Direct, Proquest, EBSCO dan Google Scholar dalam bentuk jurnal penelitian dan artikel dari tahun 2010 sampai dengan tahun 2017. Jurnal penelitian dan artikel yang diperoleh kemudian dilakukan review untuk memilih jurnal penelitian dan artikel yang sesuai dengan kriteria inklusi, yaitu remaja putri usia 12-19 tahun yang sedang menstruasi. Jurnal penelitian dan artikel yang digunakan sebagai sampel selanjutnya diidentifikasi.

\section{Hasil dan Pembahasan}

Masa remaja merupakan masa peralihan dari pubertas ke dewasa, yaitu pada umur 11 sampai 20 tahun. Pada masa remaja individu matang secara fisiologik, psikologik, mental, emosional dan sosial. Terjadi banyak perubahan yang ditandai munculnya karakteristik seks primer yang dipengaruhi oleh mulai bekerjanya kelenjar reproduksi. Muculnya haid yang pertama kali (menarche) menandakan ciri-ciri terjadinya seks primer. Perubahan ini akan terjadi bersamaan perubahan fisik lainnya. Pada remaja putri pubertas ditandai dengan datangnya haid. Haid merupakan proses keluarnya darah dari rahim melalui vagina setiap bulan selama masa subur.Siklus haid biasanya teratur tetapi tak jarang juga siklus yang tidak teratur terjadi. Hal ini biasanya disebabkan faktor penyesuaian terhadap hormon reproduksi dan aktifitas serta pengaruh dari stressor internal. Haid yang dialami wanita remaja dapat menimbulkan masalah, salah satunya adalah nyeri haid (dismenorrhoe).

Nyeri menstruasi sebenarnya merupakan masalah ginekologis yang paling umum terjadi pada wanita remaja maupun dewasa, namun menjadikan suatu kondisi yang merugikan bagi banyak wanita yang berpegaruh terhadap kualitas hidup terkait kesehatan. Nyeri menstruasi terkadang menyebabkan wanita tidak dapat beraktifitas secara normal dan dapat berdampak dari sisi ekonomi, karena berhubungan dengan biaya yang dikeluarkan untuk pembelian obat 
serta perawatan medis. Bagi remaja putri yang duduk di bangku sekolah menjadi suatu kendala dikarenakan dapat menyebabkan konsentrasi belajar dan motivasi belajar menjadi menurun karena nyeri menstruasi yang dirasakan.

Sebanyak $90 \%$ dari remaja perempuan di seluruh dunia mengalami masalah saat menstruasi dan lebih dari $50 \%$ dari perempuan yang sedang menstruasi mengalami nyeri menstruasi dengan 10-20\% dari mereka mengalami gejala yang cukup parah. Prevalensi nyeri menstruasi di Indonesia sebesar $64,25 \%$ yang terdiri dari $54,89 \%$ nyeri menstruasi primer dan $9,36 \%$ nyeri menstruasi sekunder. nyeri menstruasi primer dialami oleh $60-75 \%$ remaja dengan tiga perempat dari jumlah remaja tesebut mengalami nyeri ringan sampai berat dan seperempat lagi mengalami nyeri berat (Larasati dan Faridah Alatas, 2016).

Nyeri menstruasi adalah nyeri perut yang berasal dai kram rahim yang terjadi selama menstruasi. Biasanya timbul pada permulaan menstruasi dan berlangsung beberapa jam hingga beberapa hari hingga mencapai puncak nyeri. Nyeri menstruasi terbagi menjadi nyeri menstruasi primer dan sekunder. Nyeri menstruasi primer tidak didasari dengan kondisi patologis sedangkan nyeri menstruasi sekunder merupakan nyeri menstruasi yang didasarkan pada kondisi patologis seperti ditemukannya endometriosis atau kista ovarium. Waktu awal nyeri menstruasi primer biasanya terjadi dalam waktu 6 sampai 12 bulan setelah menarrche dengan durasi nyeri umumnya 8 sampai 72 jam. Nyeri menstruasi primer berkaitan dengan kontraksi otot miometrium dan sekresi prostaglandin sedangkan nyeri menstruasi sekunder disebabkan adanya masalah patologis di rongga panggul.

Ada beberapa cara untuk mengurangi keluhan pada nyeri menstruasi primer tersebut, misalnya dengan penggunaan kompres hangat, mengkonsumsi obat-obatan pengurang rasa nyeri (analgetik), olah raga secara teratur, akupunktur dan mengkonsumsi produk-produk herbal/jamu yang telah dipercaya khasiatnya. Tetapi dari beberapa penelitian yang sudah dilakukan terbukti bahwa mengkonsumsi produk-produk herbal/jamu, salah saatunya minuman kunyit asam bisa mengurangi nyeri saat menstruasi karena kandungan curcumin dan asam pada minuman kunyit asam tersebut.

Kebiasaan minum jamu atau produk herbal salah satunya adalah kunyit asam, bukanlah suatu hal yang asing lagi bagi masyarakat di Indonesia khususnya Jawa dan Madura bahkan di dunia juga sudah mengenal herbal kunyit asam ini. Kunyit asam diyakini berkhasiat untuk mengurangi keluhan nyeri menstruasi dan sudah menjadi suatu kebiasaan turun temurum yang digunakan masyarakat. Produk herbal/jamu atau fitofarmaka saat ini memang sedang menjadi alternative utama bagi para remaja putri yang ingin mengurangi rasa nyeri menstruasi tanpa mendapat efek samping, yaitu dengan mengkonsumsi minuman kunyit asam.

Minuman kunyit asam adalah suatu minuman yang diolah dengan bahan utama kunyit dan asam. Secara alamiah kunyit dipercaya memiliki kandungan bahan aktif yang dapat berfungsi sebagai analgetika, antipiretika dan antiinflamasi, begitu juga asam (asam jawa) yang memiliki 
bahan aktif sebagai antiinflamasi, antipiretika dan penenang. Hasil penelitian sebelumnya menunjukkan bahwa kurkumin aman dan tidak toksik bila dikonsumsi oleh manusia, jumlah kurkumin yang aman dikonsumsi oleh manusia adalah 100 mg/hari. Minuman kunyit asam sebagai pengurang rasa nyeri pada nyeri menstruasi primer memiliki efek samping minimal dan tidak ada bahaya jika dikonsumsi sebagai suatu kebiasaan (Agus Winarno, 2014).

Berdasarkan penelitian yang dilakukan oleh Agus Winarno (2014) untuk melihat pengaruh minum kunyit asam terhadap penurunan tingkat nyeri dismenorrhoe 44 siswi MTsN Jatinom Klaten, didapatkan bahwa tingkat nyeri dismenorea siswi sebelum minum kunyit asam dari 44 responden yaitu 33 $(75 \%)$ dengan tingkat nyeri ringan dan $11(25 \%)$ dengan tingkat nyeri sedang. Setelah minum kunyit asam ada responden yang tidak nyeri lagi sejumlah 17 (38,6\%), nyeri ringan sejumlah $21(47,7 \%)$ dan nyeri sedang sejumlah $6(13,6 \%)$. Hasil penelitian menunjukkan adanya penurunan tingkat nyeri dismenorea setelah responden minum kunyit asam. Hasil uji statitistika diperoleh nilai $\mathrm{p}=0,000$ $(\mathrm{P}<0,05)$ menunjukkan ada pengaruh minum kunyit asam dengan penurunan tingkat nyeri dismenorea pada siswi MTsN Jatinom Klaten. Secara teori kandungan yang terdapat dalam kunyit asam adalah Curcumine dan anthocyanin akan bekerja dalam menghambat reaksi cyclooxygenase (COX) sehingga menghambat atau mengurangi terjadinya inflamasi yang akan mengurangi atau bahkan menghambat kontraksi uterus. Mekanisme penghambatan kontraksi uterus melalui curcumine adalah dengan mengurangi influx ion kalsium $(\mathrm{Ca} 2+)$ ke dalam kanal kalsium pada sel-sel epitel uterus. Kandungan tannins, saponins, sesquiterpenes, alkaloid dan phlobotamins akan mempengaruhi system saraf otonom sehingga bisa mempengaruhi otak untuk bisa mengurangi kontraksi uterus. Curcumenol sebagai agen analgetika akan menghambat pelepasan PG yang berlebihan.

Penelitian lainnya di luar negeri, yaitu Teheran (Iran) meneliti tentang kurkumin terhadap penurunan gejala Premestrual Syndrom (PMS). Penelitian ini merupakan uji klinis yang bertujuan mengevaluasi efek dari curcumin terhadap penurunan gejala PMS. Studi double blind, setelah orang diidentifikasi mengalami PMS, sampel diacak. Jumlah sampel sebanyak 35 diberi plasebo dan 35 diberi curcumin. Kemudian setiap peserta menerima dua kapsul setiap hari selama tujuh hari sebelum menstruasi dan selama tiga hari setelah menstruasi selama tiga siklus berturut-turut dan mereka dipantau keparahan dari gejala yang ada dengan catatan kuesioner harian. Hasil penelitian didapatkan gejala ringan/dasar dari PMS sebelum dintervensi tidak berbeda antara kelompok. Sementara setelah tiga siklus pengobata berturut-turut dengan kurkumin, jumlah keparahan skor PMS telah berkurang dari 102,06 \pm 39,6442,47 $\pm 16,37$ (berarti perubahan: 59,59; 95\% confidence interval [CI]: 46,19-72,99) dan Placebo. Total beratnya PMS skor berubah dari $106,06 \pm 44,12-91,60 \pm 43,56$ (berarti perubahan: 14,45 ; $95 \%$ CI: 2,6926,22). Selain itu, perbedaan antara perubahan berarti signifikan (berarti perbedaan: 45.14; 95\% CI: 6.10-14.98). Hal ini membuktikan bahwa 
untuk pertama kalinya menunjukkan efek menguntungkan potensi kurkumin dalam menurunkan keparahan gejala PMS, yang dimungkinkan karena dimediasi oleh modulasi neurotransmiter dan efek anti-inflamasi kurkumin. Curcumin adalah kurkuminoid utama dari bumbu kunyit, yang merupakan anggota dari keluarga jahe (Zingiberaceae). Kurkumin mengurangi gejala PMS melalui peningkatan kadar serum BDNF. Meskipun penelitian yang lebih besar diperlukan, penelitian ini menunjukkan bahwa kurkumin dapat dianggap sebagai pilihan terapi yang efektif untuk PMS (Hamed Fanaei dkk, 2016).

\section{Simpulan}

Nyeri menstruasi adalah nyeri perut yang berasal dari kram rahim yang terjadi selama haid. Biasanya timbul pada permulaan haid dan berlangsung beberapa jam sampai dengan beberapa hari mencapai puncak nyeri. Nyeri menstruasi sebenarnya merupakan masalah ginekologis yang paling umum terjadi pada wanita remaja maupun dewasa, namun menjadikan suatu kondisi yang merugikan bagi banyak wanita yang berpegaruh terhadap kualitas hidup terkait kesehatan.

Nyeri menstruasi terkadang menyebabkan wanita tidak dapat beraktifitas secara normal dapat berdampak dari sisi ekonomi, karena berhubungan dengan biaya yang dikeluarkan untuk pembelian obat, dan perawatan medis. Untuk mengurangi keluhan pada saat nyeri menstruasi, hal yang dapat dilakukan adalah dengan mengkonsumsi herbal atau jamu, yaitu minuman kunyit asam yang dikonsumsi selama menstruasi, sehari 2x sebanyak 1 gelas pada pagi hari dan sore hari sesudah makan.

Minuman kunyit asam adalah suatu minuman yang diolah dengan bahan utama kunyit dan asam. Secara alamiah kunyit dipercaya memiliki kandungan bahan aktif yang dapat berfungsi sebagai analgetika, antipiretika dan antiinflamasi, begitu juga asam (asam jawa) yang memiliki bahan aktif sebagai antiinflamasi, antipiretika dan penenang.

Tenaga kesehatan dan masyarakat dapat menggunakan terapi minuman kunyit asam sebagai salah satu alternatif pengganti obat untuk mengurangi tingkat nyeri saat menstruasi.

\section{Daftar Pustaka}

American Family Physician. (2014). Diagnosis and Initial Management of Dysmenorrhea. Dallas, Texas: University of Texas Southwestern Medical Center.

Anugroho \& Wulandari. (2011). Cara Jitu Mengatasi Nyeri haid. Yogyakarta: C.V ANDI OFFSET.

Leli, Rahmawati \& Atik. (2011). Pengaruh kunyit asam terhadap penanganan nyeri haid pada siswi Kelas XI SMA Negeri I Sugihwaras.

Kylenorton. (2010). Menstruation Disorders - Dysmenorrhea - How Chinese Herbs Can Help to Treat and Prevent Dysmenorrhea.

Sina, M. Yusuf. (2012). Khasiat super minuman alami tradisional beras kencur \& kunyit asam 
menyehatkan dan menyegarkan tubuh tanpa efek samping. Yogyakarta: Diandra Pustaka Indonesia.

Marlina E. (2012). Pengaruh Minuman Kunyit Asam Terhadap Tingkat Nyeri Dismenorea Primer Pada remaja Putri di SMA Negeri 1 Tanjung Mutiara Kabupaten Agam. Fakultas Keperawatan Universitas Andalas.

Fanaei H, Khayat S, Kasaeian A, Javadimehr M. (2016). Effect of curcumin on serum brain-derived neurotrophic factor levels in women with premenstrual syndrome: A randomized, doubleblind, placebo-controlled trial. Neuropeptides; 56:25-31.

Marsaid M, Nurjayanti D, Rimbaga Y.A. (2017). Efektifitas pemberian ekstrak kunyit asam terhadap penurunan dismenore pada remaja putri. Global Health Science (GHS): 2(2).

Larasati, T., \& Alatas, F. 2016. Dismenore primer dan faktor risiko Dismenore primer pada Remaja. Jurnal Majority: 5(3), 7984.

Winarso, A. (2014). Pengaruh minum kunyit asam terhadap penurunan tingkat nyeri dismenorea pada siswi di madrasah tsanawiyah negeri jatinom klaten. Interest: Jurnal Ilmu Kesehatan, 3(2). 